\title{
Belis dan Perilaku Memilih Perempuan di Kabupaten Nagekeo, Flores, Nusa Tenggara Timur
}

\section{Belis and Behavior of Hoosing Women in Nagekeo District, Flores, East Nusa Tenggara}

\author{
Dwiganura Apu* \\ Magister Ilmu Politik, Fakultas Ilmu Sosial Dan Politik, Universitas Diponegoro, Indonesia
}

Diterima: 08 Juni 2020; Disetujui: 13 Desember 2020; Dipublish: 31 Januari 2021

\begin{abstract}
Abstrak
Tulisan ini bertujuan untuk mengkaji keterkaitan antara pernikahan/perkawinan dengan sistem belis (mas kawin/mahar) dan kepatuhan (istri) terhadap suami, serta apakah kedua faktor tersebut mempengaruhi perilaku memilih kaum perempuan pada pemilihan umum di Nagekeo. Perkawinan dengan pemberian belis yang dirasakan cukup bernilai ekonomis yang tinggi menuntut tingkat kepatuhan istri terhadap suami, karena dengan pemberian belis, suami merasa memiliki kuasa penuh terhadap perempuan guna mendekati masalah ini dipergunakan acuan teori dari konsep Gender and Development, sehingga mengetahui sejauh mana perempuan ikut terlibat dalam menentukan pilihannya sendiri, tidak hanya dalam ruang lingkup yang lebih luas, tetapi dalam lingkup kecil didalam keluarga juga. Data-data dikumpulkan melalui wawancara mendalam dengan narasumber, dan dianalisis secara kualitatif. Kajian ini menyimpulkan bahwa belis disini merupakan suatu warisan budaya yang terkandung dengan nilai - nilai historis dan sosial didalamnya. Namun, belis tidak berpengaruh penuh terhadap tingkat kepatuhan serta perilaku memilih perempuan pada Pemilu di Nagekeo.

Kata Kunci: Belis, Kepatuhan Terhadap Suami, Perilaku Memilih
\end{abstract}

\begin{abstract}
This paper aims to examine the relationship between marriage / marriage with the belis system (dowry /dowry) and obedience (wife) to the husband, and whether these two factors influence women's voting behavior in the general election in Nagekeo. . Marriage by giving a belis that is felt to be of high economic value demands the wife's level of compliance with her husband, because with the granting of belis, the husband feels he has full power over women to approach this problem using the theoretical reference from the concept of Gender and Development, thus knowing the extent to which women are involved in determining their own choices, not only in a wider scope, but in a small scope within the family as well. Data collected through in-depth interviews with informants, and analyzed qualitatively. This study concludes that belis here is a cultural heritage contained with historical and social values in it. However, the belis did not have a full effect on the level of compliance and voting behavior of women in the elections in Nagekeo. Keywords: Belis, Compliance with Husband, Selecting Behavior
\end{abstract}

How to Cite: Apu, D. (2021). Belis dan Perilaku Memilih Perempuan di Kabupaten Nagekeo, Flores, Nusa Tenggara Timur. PERSPEKTIF, 10 (1): 1-9.

*Corresponding author:
E-mail: mbataangi@gmail.com ISSN 2085-0328 (Print) ISSN 2541-5913 (online) 


\section{PENDAHULUAN}

Perkawinan/pernikahan dengan sistem belis ini merupakan salah satu ciri masyarakat patrilinieal. Masyarakat patrilinieal adalah masyarakat yang mengikuti garis keturunan ayah (suami). Ayah (suami) dinilai sebagai penerus keturunan suku, demikian pula selanjutnya anak laki-lakinya. Garis keturunan suku bukan diambil dari garis ibu (istri) di dalam keluarga, melainkan lewat garis ayah (suami). Dalam masyarakat patrilinieal, eksistensi keluarga sangat ditentukan oleh eksistensi suami. Suami berperan penuh sebagai pengatur rumah tangga termasuk istrinya dan seluruh anggota keluarga. Istri hanya sebagai pelengkap suami.

Dalam masyarakat patrilinieal seperti ini yang memiliki hak menyampaikan pendapat, dan hak mengatur baik dalam rumah tangganya (keluarga inti) maupun di sukunya adalah suami (Daeng, 2006). Istri hanya sebagai pendukung dan penopang suami. Seorang istri diberikan hak untuk bicara, untuk mengajukan usul atau saran, semua tergantung suaminya. Jikalaupun suami memberikan kebebasan bagi istrinya untuk mengajukan usul atau saran, itu hanya boleh dalam lingkup keluarga kecilnya. Untuk urusan di luar lingkungan keluarga kecilnya, semua usul/saran tersebut harus disampaikan melalui suami, dan apakah usul/saran tersebut diteruksan atau tidak kepada yang berwenang, semua tergantung penuh pada suaminya. Suami berhak meneruskan atau menghentikan (Djawanai dan Ngani, 2006). Suami juga berhak mengatur istrinya dalam segala aspek, bahwa semua keputusan akhir adalah mutlak berasal dari keputusan suami atau laki-laki.

Pernikahan dengan sistem belis ini, ditandai dengan adanya pemberian belis dari pihak keluarga pria, kepada pihak perempuan, yang mana pemberian belis ini sesuai dengan kesepakatan kedua pihak. Adapun pemberian belis di sini berupa sejumlah uang, hewan dan barang yang telah disepakati bersama, dalam budaya masyarakat setempat pemberian belis dengan jumlah besar terkadang terasa memberatkan bagi pihak laki - laki dari nilai ekonomis belis tersebut.

Dari pemberian belis tersebut yang bagi sebagian masyarakat dirasakan sangat berat, kemudian penulis mencoba menghubungkan pengaruh pemberian belis, dengan kepatuhan istri dalam keluarga, apakah berpengaruh terhadap perilaku memilih perempuan Nagekeo pada pemilu. Adapun penelitian terdahulu yang penulis jadikan sebagai acuan antara lain sebagai berikut, penelitian dari (Seba, 2016)Kekerasan Terhadap Perempuan Bagian Dari Pergeseran Nilai Budaya Belis Di Flores Nusa Tenggara Timur.

Tujuan penelitian ini agar mengetahui dan menganalisis pergeseran makna budaya belis, yang mengakibatkan kekerasan, yang mana pada dasarnya belis berfungsi untuk mempererat hubungan kekerabatan antara kedua belah pihak keluarga, namun yang kemudian yang terjadi adalah belis kemudian menjadi sumber kekerasan dalam keluarga. Pada penelitian terdahulu yang kedua, peneliti mengambil penelitian terdahulu dari (Ndapadingi, 2003). Tradisi Belis Dan Praktek Kekerasan Terhadap Perempuan Di Sumba Timur. Pada penelitian ini, penulis menemukan bahwa belis, yang di dalam budaya Sumba, dan Merapu khususnya, bermakna sebagai penghormatan dan penghargaan terbesar kepada perempuan Sumba, dan sebagai perekat hubungan kedua keluarga besar (Engo, 2016).

Akan tetapi menjadi distorsi pemutar balikan pemahaman, fakta, dan sebagainya yang kemudian digunakan untuk mencari keuntungan semata, dari salah satu pihak, dan kemudian dalam perjalanannya, menjadi beban baru bagi kaum perempuan, dalam hal ini istri yang di belis tersebut, beban ganda oleh istri, dan kemudian penelitinya, memberikan uraian bahwa, 
apapun status sosial istri, apapun pekerjaan istri atau perempuan, tidaklah terlepas dari perlakuan tidak menyenangkan dalam rumah tangga, entah itu secara fisik, psikis, ekonomi, dan seksual, dan itu semua berasal dari faktor belis, semakin mahal atau tingginya belis yang diberikan pihak suami kepada orang tua atau pihak keluarga perempuan, semakin tinggi dan berat beban moril yang dipikul oleh perempuan di dalam rumah tangga (Neonnub, 2018; Raga, 2008; Soro, 2018).

Penelitian terdahulu berikutnya adalah penelitian dari Irmayani (2012; 2011) dan Hasibuan \& Irmayani (2017), Perilaku Perempuan Pemilih Dalam Menetapkan Pilihan Pada Pemilu 2009. Pada penelitian ini, penelitinya memberikan gambaran bahwa suara perempuan dalam pemilu sangat berarti dalam proses demokrasi, karena dari segi kuantitatif, perempuan merupakan basis pemilih terbesar yang dapat mendulang suara yang menguntungkan bagi partai politik. Namun, pada kenyataannya perempuan memiliki ketergantungan yang sangat besar dalam bersikap, berperilaku dan mengambil keputusan terhadap suami, saudara, dan Kyiai.

Penelitian terdahulu berikutnya adalah penelitian dari Aisyah (2013). Relasi Gender Dalam Institusi Keluarga, Pandangan Teori Sosial Dan Feminis. Penulis menemukan bahwa berangkat dari realitas hubungan gender dalam institusi keluarga yang dikhotomis, menyebabkan ketimpangan antara kaum pria dan wanita, kemudian dengan bersamaan mengakui bahwa unsur kultur dan sosial mempunyai nilai penting terhadap pembagian fungsi yang dipakai oleh pria (suami), dan wanita (istri) dalam institusi keluarga, ini berarti bahwa konstruksi sosial budaya sangat berperan dalam penciptaan hubungan berkontribusi antara pria dan wanita.

Tujuan penelitian untuk mengkaji keterkaitan antar pernikahan/perkawinan dengan sistem belis (mas kawin/mahar) dan kepatuhan (istri) terhadap suami, serta apakah kedua faktor tersebut mempengaruhi perilaku memilih kaum perempuan pada pemilihan umum di Nagekeo.

Untuk membahas permasalahan ini, penulis menggunakan pendekatan Gender and Development, yang mana pendekatan ini lahir sebagai kritik dari persoalan ketidakadilan gender, yang kemudian dikaitkan dengan budaya masyarakat setempat dalam pemberian belis kepada perempuan, yang dalam kehidupan berumah tangga sebagai dampak dari pemberian belis ini, kemudian pihak laki laki dalam posisi dominan terhadap istrinya dalam tiap aspek kehidupan.

\section{METODE PENELITIAN}

Penelitian ini

menggunakan penelitian deskriptif kualitatif yaitu penelitian yang mempunyai tujuan untuk mendeskripsikan hasil temuan. Pada Moleong menguraikan bahwa metode penelitian kualitatif menghasilkan data deskriptif berupa lisan maupun kata tertulis dari sumber yang diamati (Moleong, 2017). Fokus penelitian ini adalah berusaha menemukan hal- hal yang terkait dengan pernikahan dengan sistem belis, kepatuhan seorang istri kepada suami terhadap perilaku memilih pada kaum perempuan. Peneliti mengambil lokasi penelitian di Kabupaten Nagekeo, Flores, Nusa Tenggara Timur, pemilihan lokasi ini didasarkan atas beberapa pertimbangan yang mana salah satunya adalah Kabupaten Nagekeo merupakan salah satu kabupaten pemekaran baru di Nusa Tenggara Timur, yang mana masih kental adat dan budayanya terkait budaya patriarkhi.

Informan yang dijadikan sebagai sumber data adalah Tokoh adat, yang dinilai mengetahui, memahami, dan menguasai hal yang berkaitan dengan perkawinan berbelis tersebut, serta perempuan yang menikah dan yang melakukan pencoblosan saat pemilu, serta 
suami juga dijadikan narasumber, dan tokoh masyarakat dan aktivis partai politik.

Dalam memperoleh data, maka peneliti menggunakan wawancara tidak terstruktur, yaitu bahwa wawancara disebut tidak berstruktur maksudnya pewawancara tidak memasuki situasi wawancara dengan urutan pertanyaan yang terencana, dengan kata lain mengallir begitu saja (Bungin, 2005), hal ini dikarenakan situasi di lokasi penelitian terkait dengan informan, karena informan yang sebagian besar bermata pencarian sebagai petani, dengan waktu kerja yang berat, sehingga saat diwawancarai, informan memberikan informasi dengan bercerita cepat, kemudian kembali ke pekerjaannya. Selanjutnya terkait teknik analisis data menggunakan model Miles dan Huberman dalam Masyhuri dan Zainuddin (2013), meliputi: reduksi data, dan menarik kesimpulan. Data mentah yang diperoleh dari informan, kemudian dipilah sesuai dengan topik penelitian, untuk kemudian diambil kesimpulannya.

\section{HASIL DAN PEMBAHASAN \\ Perkawinan dengan Sistem Belis}

Belis atau mahar yang dimaksudkan dalam penelitian ini adalah keseluruhan barang baik uang, hewan, perhiasan, dan lain-lain yang diserahkan oleh calon pengantin laki-laki (calon suami) dan keluarga kepada keluarga calon pengantin perempuan (calon istri) sesuai kesepakatan pada saat lamaran. Pembayaran belis (mas kawin) ini merupakan syarat mutlak yang harus dipenuhi sebelum calon suami secara resmi menikahi calon istrinya tersebut, perkawinan dengan memberikan barang atau belis tersebut pada umumnya berlaku pada lingkungan masyarakat adat yang mempertahankan garis keturunan bapak.

Pada hukum adat perkawinan ada aturan ataupun tahapan - tahapan yang harus dilalui, salah satu tahapan dalam hukum adat di Nagekeo itu sendiri adalah pemberian belis, atau mahar itu tersebut, jadi walaupun sudah berlaku Undang -
Undang perkawinan yang bersifat nasional, namun dalam berbagai golongan masyarakat di berbagai daerah yang masih berlaku hukum perkawinan adat.

Mengapa membayar belis/mas kawin menjadi syarat mutlak untuk pernikahan di Nagekeo, berikut beberapa jawaban dari para informan.

"Buat belis itu sangat penting, karena menyangkut budaya kita orang Nage, harus antar belis, supaya perempuan ikut masuk ke adat laki - laki, tidak ada pengecualiannya jadi harus bayar belis. Dengan kasi belis itu merupakan tanda kalau laki-laki dan keluarganya memang benar-benar serius mau peristri perempuan. Belis yang diminta biasanya lumayan besar. Kalau itu terbukti bisa dipenuhi berarti dia siap dan mampu kasi hidup istrinya nanti, bukan untuk satu dua hari tetapi seumur hidup. (Bpk Zakharias Selah Nuwatiwa, tetua adat Rendu, Nagekeo, (wawancara tanggal 18 juli 2019).

Hasil wawancara lainnya terkait dengan pemberian belis kepada pihak perempuan "Belis itu penting sekali ema (anak), karena adat orang Nage, adat kita disiini ambil istri harus pake belis, kalo tidak kita laki harga diri tidak ada, kalo kita pake belis kita laki harga diri tinggi, orang tidak remeh liat kita, kita ada kuasa dengan istri juga." wawancara dengan Bapak Arnoldus Epe, usia 52 tahun, wawancara tanggal 18 juli 2019.

Adapun hasil wawancara lainnya terkait belis tersebut "ae belis itu penting ema (anak) itu wajib itu ganti aer susu ine (mama) punya, itu harus buat, tidak bisa tidak ema, itu kalo ema tidak buat orang bilang isi ae mona (laki - laki yang tidak punya apa apa)" wawancara dengan Bapak Kristianus Laki, usia 50 tahun, pada tanggal 20 juli 2019. "belis itu penting, harus kasi, harus lunas, itu penghargaan untuk ine (mama) karna kalo tidak ada belis itu murahan, harus belis " wawancara dengan Bapak Antonius Longga Woda, usia 73 tahun, pada 28 juli 2019. 
Dari beberapa pernyataan narasumber di atas dapat diketahui bahwa pentingnya pemberian belis atau mas kawin kepada pihak perempuan dalam budaya adat Nage, kemudian belis ini dipandang dengan nilai suatu harga diri bukan hanya seseorang, tapi juga keluarga besar pada umumnya, tidak hanya harga diri dari laki - laki sebagai pemberi belis, tetapi juga perempuan sebagai penerima, bahwa ketika perkawinan itu tidak di dahului dengan pemberian belis, stigma yang muncul di mata masyarakat adat dan sosial bahwa tidak ada belis dianggap sebagai tidak ada harganya, murahan begitu, dan tidak dipandang di dalam kehidupan masyarakat adat dan masyarakat umum.

\section{Partisipasi Perempuan, dalam Menentukan Pilihannya Pada Pemilu}

Perilaku memilih menurut Surbakti (1999) adalah: "Aktivitas pemberian suara oleh individu yang berkaitan erat dengan kegiatan pengambilan keputusan untuk memilih atau tidak memilih, dalam suatu pemilihan umum. Bila memutuskan untuk memilih, maka akan memilih/mendukung kandidat tertentu". Metode community dynamic study tampaknya memadai untuk digunakan dalam memperoleh gambaran yang cukup komprehensif tentang fenomena pemilih dalam pemilu secara langsung. Asumsi bahwa tingkah laku politik sangat dipengaruhi oleh situasi lingkungan dimana seseorang berada.

1. Mengikuti pilihan suami

Para informan mengaku bahwa bagi masyarakat patriarkhi seperti di Kabupaten Nagekeo ini, yang memilih hak pilih dan hak suara dalam urusan adat adalah laki-laki (suami), istri harus mengikuti apapun pilihan dan kebijakan suami. Lalu karena keterbatasan pengetahuan, dalam hal-hal lain pun sekarang istri mengikuti arahan suaminya, termasuk dalam pilihan politik ketika Pemilu kemarin apakah suami menentukan, dan mengarahkan pilihan istri? Hal ini tercermin dari penyataan para informan berikut: "iya, pemilu kemarin suami suruh saya pilih, kasi tunjuk kasi arahan supaya pilih yang itu, dalam bilik suara, iya saya pilih ikut yang suami suruh " wawancara dengan Mama Yosfina Wangu, umur 57 tahun, tanggal 28 Juli 2019.

Dari kutipan tersebut bahwa ada arahan dari suami, dan suami juga ikut menentukan agar ketika dalam bilik suara untuk memilih sesuai dengan yang disepakati sebelumnya, dan ketika berada didalam bilik suara, istri kemudian menentukan pilihan sesuai dengan arahan dari suaminya.

"ow pemilu kemarin, saya ikut suami le ade, suami bilang kami pilih yang sama presiden dengan caleg tu, suami kasi suruh bilang pilih yang ikut dia, iya sampe di dalam bilik suara, saya ikut yang suami sudah bilang malam tu." wawancara dengan Mama Maria Imakulata Sada, usia 30 tahun, tanggal 31 Juli 2019

"iya ikut, tapi tidak ada paksa - paksa dari suami, hanya suruh bilang besok pilih ikut dia, iya terus di itu tempat tusuk tu, saya tusuk seperti yang bilang." wawancara dengan Mama Modesta Modhe, usia 48 tahun, pada tanggal 20 Juli 2019.

Pernyataan dari mama Yosfina Wangu, mama Maria Imakulata Sada, dan juga mama Modesta Modhe, ini mewakili banyak istri yang merasa diri tidak tahu apa-apa mengenai politik, sehingga merasa perlu mengikuti arahan suami. Suami sebagai kepala rumah tangga dianggap yang paling tahu dan siap mengarahkan pilihan keluarganya. Sebagai kepala keluarga dia pasti akan mengarahkan pada pilihan yang terbaik.

Sikap istri ini yang dapat dilihat beberapa kutipan wawancara berikut

"itu saya yang suruh pilih, itu saya suruh, benar - benar kamu yang caleg jangan bikin bodoh saya punya keluarga dalam suku, dalam rumah ini, iya karena saya pake belis itu juga, kalo dalam bilik suara harus ikut, pasti ikut ikut, karna kalo pas siar jumlah suara, yg saya kode tidak 
ikut, nanti kena sasaran, harus ikut saya." wawancara dengan Bapak Antonius Longga Woda, usia 73 tahun, pada 28 juli 2019.

Dari kutipan wawancara diatas dengan Bapak Antonius Longga, bapak Antonius ini menyatakan dengan tegas dan keras, bahwa apa yang diarahkan dan disuruh oleh beliau harus dipatuhi dan dilaksanakan oleh istri dan anggota keluarga didalam rumahnya, sempat menyinggung terkait dengan faktor belis, yang menurut bapak Anton sebagai salah satu faktor juga bahwa istrinya pasti akan patuh dan ikut suruhan dan arahan yang diberikannya.

Adapun hal senada di sampaikan oleh informan dalam wawancara berikut "iya, iya saya arahkan saya suruh kalo pilih, kemarin kami pilih Jokowi, iya biar legislatif juga kami sama, saya suruh, namanya juga suami istri hidup sama, jadi tidak boleh sendiri - sendiri, harus sama - sama, satu konsep." wawancara dengan Bapak Lorensius Goa, umur 40 tahun, pada 31 Juli 2019 " iya, saya kasi arahan, kami dsini Jokowi, dari awal hanya Jokowi saja, kalo anggota DPR kemarin kalo pusat Anwar Pua Geno, dengan Thomas Tiba. Bukan karna belisnya, dia harus ikut. Saya arahkan ator secara keluarga, bagi, kalo disini untuk Anwar Pua Geno, kalo Aesesa Selatam disini bagi. Ha`a ka, dalam bilik tu, pasti isttri pilih itu, pasti pilih itu." wawancara dengan Bapak Kristianus Laki, usia 50 tahun, pada tanggal 20 juli 2019.

Dari kutipan wawancara diatas dengan Bapak Lorensius Goa dan Bapak Kristianus Laki, dapat dilihat bahwa suami berperan besar dalam memberikan arahan kepada istri untuk memilih sesuai dengan apa yang telah ditentukan.

Bahwa kemudian disini, istri tidak mempunyai pilihan lain selain mengikuti apa yang telah di tentukan oleh suami, bahkan ketika didalam bilik suara, suami begitu yakin bahwa istri tetap akan memilih sesuai petunjuk dan arahan dari suami, dan tidak mungkin tidak untuk istri ketika didalam bilik suara memilih yang lain, dan suami menjamin bahwa sekalipun didalam bilik tertutup itu, istri pasti tetap pilih sesuai dengan amanat dari suami. Kutipan wawancara tersebut kemudian memberikan gambaran bahwa pendekatan Gender and Development (GAD) yang mana merupakan pendekatan dengan fokus pada relasi gender dan keterlibatan perempuan secara optimal didalam ruang publik, seharusnya dalam pendekatan ini, kiranya membentuk terciptanya kesetaraan antara laki - laki dan perempuan, sehingga kemudian mengenai pandangan dasar terkait dominasi pria terkait sosial, ekonomi, dan struktur politik (Kristianti, 2016). Seharusnya jika ditinjau dari pendekatan Gender and Development ini, membuka sekat pembatas antara lakilaki dan perempuan termasuk didalam pengkotakan peran dalam berbagai struktur didalam masyarakat, yang mana menurut pemikir Gender and Development bahwa seharusnya tidak ada jurang pembatas sehingga baik laki-laki maupun perempuan mempunyai keasempatan yang sama, namun kenyataan dari petikan wawancara di atas laki-laki mengambil peran lebih dalam area politik di tingkat komunitas.

Hal ini dipertegas dengan kutipan wawancara berikut ini " oh iya, itu kita bagi suara, jelas ada arahan dari suami, disini didalam rumah adat ini, saya omong dari pilih presiden sampe pilih caleg, saya suruh pilih, termasuk pilih kepala desa ini, itu saya suruh, satu suara dari saya, saya yang arahkan." (Bpk Zakharias Selah Nuwatiwa, tetua adat Rendu, Nagekeo, (wawancara tanggal 18 juli 2019).

"oh iya, waktu pemilu kemarin, saya bilang kita ni pilih Jokowi, kalo legislatif saya bilang kita tusuk Dipo Nusantara, ai itu jelas dalam bilik suara pasti istri ikut, ow bukan seperti itu, bukan karna saya pake belis jadi istri patuh waktu pemilu kemarin, bukan seperti itu, hanya suami istri saling menyatu, istri pasti patuh" wawancara dengan Bapak Arnoldus Epe, usia 52 tahun, wawancara tanggal 18 juli 2019. 
Hal senada disampaikan dalam kutipan wawancara berikut

"Di masyarakat kita Nage ni, selama ini yang banyak sibuk dengan urusan politik, biasanya orang laki. Kalo yang perempuan kalopun ada itu sedikit sekali, banyak yang tidak peduli, malas sibuk urusan yang begitu tu, mending urus kerja yang pasti - pasti, urus kebun, sawah, itu politik apa itu, biar urusan orang laki saja, mungkin pemikiran yang macam begini, yang buat perempuan kita disini tidak terlalu sibuk dengan urusan begitu, ada si ada, tapi sedikit saja, itu orang mengerti mereka, kalo yang biasa, tidak terlalu sibu ribu yang begitu ema. Apalagi kalo disini rumah adat begini, tinggal dengar, kalo bapa tua bilang itu, ha berarti itu sudah." wawancara dengan salah satu tokoh masyarakat rendu Bapak Herman Jasa Angi Sa, umur 59 tahun, pada 24 Juli, 2019.

"Ha, kalo itu tu, sudahh jelas ade, sudah jadi bagian dari strategi dari caleg caleg atau pertai, kita masok rumah adat, ato kampung adat, kita dekati ketua adat, ato ketua suku dalam rumah, itu yang pasti - pasti ade, kalo ketua sudah mau, itu hitung saja dalam kampung, kau mau laki perempuan pasti ikut kalo ema kae mosalaki yang omong, kau tidak bisa lawan lagi, itu cara orang pake slama ini yang jelas, daripada kau kumpul masa, potong babi, beli moke, omong banyak belum tentu mereka mau tusuk, pulang makan kenyang mereka sudah lupa, tapi kalo kita masok rumah adat, minta di ketua adat, itu kau biar laki perempuan pasti ikut, kalo bilang belis pengaruh dengan patuh itu pasti ada kalo kita dsni, tapi kalo bilang pengaruh belis untuk tusuk pas pemilu, ae saya rasa tidak ada hubungan ew ade, tapi kalo bilang kepala yang omong, pasti orang ikut, biar kau laki dalam kampung pasti ikut, apalagi kau yang ine ebu, ata fai (perempuan)" wawancara dengan Bapak Donatus Nadho, salah satu aktivis parpol, dan toko pemuda, umur 46 tahun, pada 3 Agustus2019.

\section{Memilih Dengan Pilihan Sendiri}

Suara perempuan sangat berpengaruh dalam proses demokrasi ini, jika dilihat dari faktor kuantitatif, perempuan merupakan lumbung suara terbesar.

Berikut kutipan wawancara dibawah ini, yang mana termasuk dalam pilihan politik ketika Pemilu kemarin apakah suami menentukan, dan mengarahkan pilihan istri? apakah ketika didalam bilik suara, istri menentukan pilihan sesuai keinginannya? Hal ini tercermin dari penyataan para informan berikut:

"tidak ew, tidak ada paksaan juga, suami tidak suruh bilang pilih itu, padahal dia masuk dalam tim sukses juga tu ade, memang suami cerita bilang calon yang dia kerja, tapi tidak ada arahan dari suami untuk saya, jadi pas di dalam bilik tu, saya pilih sendiri." (wawancara dengan Mama Maria Selestina Ngodhe, Umur 37 tahun, pada tanggal 27 Juli 2019.) “ ow kemarin memang saya pu suami juga ikut tentukan, tapi saya juga menurut hak pilih, hati nurani saya sendiri to, tidak mungkin diatur, ow kalo paksa tidak ada paksa, Cuma suruh pilih yang macam omong itu, pas dalam bilik suara, saya pilih sesuai hati nurani, pilihan saya sendiri e." (wawancara dengan Mama Genderasi Tobin, usia 29 tahun, pada tanggal 22 Juli 2019)

Pernyataan yang hampir sama juga seperti wawancara diatas " iya, suami juga kastau bilang pilih sama - sama, tapi tidak ada paksaan, dari hati nurani sendiri, waktu mo tusuk tu, e tidak ada arahan dari suami e, saya pilih dari diri sendiri, hati sendiri ew." wawancara dengan Mama Susana Doi, umur 43 tahun, tanggal 22 Juli 2019

Dari kutipan wawancara, penulis dapat simpulkan bahwa suami memberikan arahan kepada istri, agar ketika dalam bilik suara untuk kemudian memilih seperti yang diarahkan, namun disini, istri membuat pilihannya sendiri sesuai dengan hati nurani dan keinginannya sendiri. Istri disini terlihat menentukan keputusan untuk memilih seperti keinginannya sendiri. 
Merujuk analisis gender yang membagi peran perempuan dalam dua ranah area yaitu produksi dan sosial kemasyarakatan dan politik, perempuan dalam area ini berusaha untuk dapat sejajar dalam menginisiasi, merencanakan, dan bahkan melaksanakannya, setidaknya dalam pengambilan keputusannya sendiri, termasuk dalam hak politiknya, dan dapat dilihat dalam kutipan wawancara berikut

"saya, pas pemilu kemarin, saya tidak mau ikut orang, biar mereka bilang tusuk ini, tusuk itu, saya tidak memang, saya pilih sendiri, saya liat baek, ikut suara saya pu hati, kalo suami, dia bilang juga, tapi tidak ew, saya pilih suara saya sendiri" wawancara dengan Mama Wadeltrudis Kodo, usia 45 tahun, tanggal 27 Juli 2019.

"oh tidak le ema, pemilu kemarin, kami dalam rumah bebas pilih suka hati, tidak ada yang paksa juga, suruh juga, kita dalam rumah bebas, mo bagi pilih yang mana, ow kalo saya dalam bilik suara, saya dari rumah niat mo pilih, sampe dalam ruangan juga, tetap seperti niat dari rumah, tidak kiri tidak kanan lagi, lurus pilih itu sudah." wawancara dengan Mama Regina Re`e, usia 50 tahun, pada tanggal 21 Juli 2019.

Berdasarkan hasil wawancara tersebut, kemudian dapat disimpulkan bahwa, istri dalam menentukan pilihan politiknya untuk memilih dalam pemilu, sesuai dengan apa yang telah direncanakan dan istri walaupun ada arahan untuk kemudian memilih seperti arahan dari suami, istri - istri tersebut tetap dengan pilihan hatinya sejak awal, dalam hal ini intervensi dari suami tidak mendapat respon dari istri - isteri mereka, yang kemudian memilih sesuai dengan pilihan hati mereka masing - masing. Hal ini kemudian diperjelas dengan hasil wawancara berikut ini dari informan

"kalo untuk pilpres, untuk arahkan istri memang iya, tapi tidak tau, pas didalam bilik suara, kalo legislatif, karna banyak ngeri calonnya tu, ada keluarga, teman juga ada, makanya kita baku bagi, tapi dalam bilik suara tidak tau lagi ew, soalnya kemungkinannya kecil, karna pas pulang kemarin, istri cerita tusuk yang lain na, tidak ikut saya." wawancara dengan Bapak Yoseph Aguino Bhia, usia 32 tahun, pada tanggal 26 Juli 2019.

"iya, kalo arahkan, tapi itu hanya omong lepas begitu saja ew, tidak paksa juga, tergantung istri mau pilih, kan dalam bilik itu sendiri yang tau saja, biar kita suruh juga, istri dalam kamar itu, sendiri sapa yang tau mau pilih apa." Wawancara dengan Bapak Herman Soter Gayus Dapa Azi, umur 44 tahun, pada tanggal 27 Juli 2019. "saya kan kerja juga, masok dalam tim dari Dipo Nusantara, tapi dalam politik tidak memaksa, hanya saya jelaskan ke istri, bilang kalo ini Dipo Nusantara ini, mungkin cocok dengan kita disini, khusus Nagekeo ini, itu saja, soal istri pillih ato tidak, saya juga tidak tau, kita tidak liat juga." wawancara dengan Bapak Benediktus Ghuta, umur 41 tahun, pada tanggal 27 Juli 2019.

Wawancara tersebut menyiratkan kesimpulan bahwa, memang ada arahan dari suami kepada istri untuk kemudian memilih pasangan calon seperti yang ditentukan suami, namun dalam hal ini, istri kemudian mempunyai pilihan mereka sendiri, dan ketika didalam biilik suara pun, mereka tetap dengan keputusan awal meraka untuk memilih seperti apa yang mau mereka pilih.

Dari uraian tersebut diketahui kalau dari dua faktor ini yang paling mempengaruhi perilaku memilih istri dalam pemilu adalah kepatuhan istri pada suami. Hampir dalam semua urusan istri akan patuh pada suami, oleh karena itu dalam hal perilaku memilihpun sangat mungkin, karena istri akan patuh kalau itu kehendak suaminya, asalkan saja suami bisa berperan sebagai kepala keluarga yang baik.

Sedangkan perkawinan dengan sistem belis hampir tidak berpengaruh pada perilaku memilih seorang istri. Belis tidak membuat kedudukan seorang istri 
lebih rendah dari suami. Karena besarnya belis yang diterima biasanya diimbangi pemberian dari keluarga perempuan yang juga tidak sedikit. Faktor belis disini tidak memberi pengaruh terhadap perilaku memilih istri, belis disini dinilai sebagai warisan budaya turun temurun, yang tetap akan selalu ada.

Perkawinan dengan sistem belis tidak memberikan pengaruh kepada perilaku memilih seorang istri pada umumnya, karena perilaku memilih istri ini, dapat dipengaruhi oleh faktor lain, bukan dari faktor perkawinan dengan sistem belis, belis adalah tradisi yang terlepas pengaruhnya kepada perilaku memilih kaum perempuan.

\section{SIMPULAN}

Perkawinan dengan sistem belis tidak berpengaruh kepada tingkat kepatuhan istri terhadap suami, dan perkawinan dengan belis juga tidak memberikan pengaruh kepada perilaku memilih seorang istri pada pemilu pada umumnya, karena perilaku memilih istri ini, dapat dipengaruhi oleh faktor lain, bukan dari faktor perkawinan dengan sistem belis, belis disini hanyalah tradisi yang terlepas pengaruhnya kepada kepatuhan seorang istri dan perilaku memilih kaum perempuan pada pemilihan umum di Nagekeo.

\section{DAFTAR PUSTAKA}

Aisyah, N., (2013), Relasi Gender Dalam Institusi Keluarga, Muwazah, 5(2).
Aisyah, N., (2013), Relasi Gender Dalam Institusi Keluarga, Pandangan Teori Sosial Dan Feminis.

Bungin, B, (2014). Analisis Data Penelitian Kualitatif, Pemahaman Filosofis dan Metodologi Kearah Penguasaan Model Aplikasi. Jakarta: PT Rajagrafindo Persada.

Daeng, Hans J, (2006). Antropologi Budaya Flores, Ende: Nusa Indah.

Djawanai, S dan Ngani, N, (2006). Adat dan Hukum Adat Ngada dan Nagekeo, Yogyakarta.

Engo, Cyrilus Ba'u (2016). Budaya Nage "Perjalanan Hidup Orang Nage di Nagekeo, Ende: Nusa Indah.

Hasibuan, M.H.F., dan Irmayani, T. (2017), Perilaku Perempuan Dalam Menentukan Pilihan Pollitik Pada Pemilu DPRD Kota Medan 2014.

Irmayani, T., (2012), Menetapkan Pilihan Pada Pemilu 2009, Jurnal Politea, 4(1).

Irmayani, T. (2011), Perilaku Perempuan Pemilih Dalam Menetapkan Pilihan Pada Pemilu 2009, 2011.

Kristianti, P, (2016). Perkawinan dan Kesetaraan Gender. Yogyakarta: Pustaka Pelajar.

Masyhuri dan Zainuddin, M. (2013). Metodologi Penelitian Pendekatan Praktis dan Aplikatif, Bandung: PT Refika Aditama.

Moleong. L.J, (2013). Metodologi Penelitian Edisi Revisi, Bandung: PT Remadja Rosdakarya.

Ndapadingi, L.H., (2013), Tradisi Belis Dan Praktek Kekerasan Terhadap Perempuan Di Sumba Timur, 2003.

Neonnub, F.I., \& Habsari, N.T., (2018), Belis: Tradisi Perkawinan Masyarakat Insana Kabupaten Timor Tengah Utara (Kajian Historis dan Budaya Tahun 2000 - 2017). Jurnal Agastya, 8(1).

Raga, Robert Aries, (2008). Antropologi Budaya Nagekeo: Sebuah Pengantar, Mbay: Ata Kita

Seba, Roberto Octavianus Cornelis., (2016), Kekerasan Terhadap Perempuan Bagian Dari Pergeseran Nilai Budaya Belis Di Flores Nusa Tenggara Timur, 2016.

Soro, I, (2018), Perlawanan Senyap Terhadap Sistem Pernikahan Adat Melalui Sastra Tulis: Novel Belis Imamat, Paramasastra, 5(1). 